\title{
The Effect of Responsibility-Based Aquatic Teaching on the Respect and Caring of Middle School Students
}

\author{
Ermawan Susanto ${ }^{1, *}$, Johan Irmansyah ${ }^{2}$, Nur Indah Pangastuti ${ }^{1}$, Fifukha Dwi Khory ${ }^{3}$ \\ ${ }^{1}$ Faculty of Sports Sciences, State University of Yogyakarta, Indonesia \\ ${ }^{2}$ Faculty of Sports Science and Public Health, Universitas Pendidikan Mandalika, Indonesia \\ ${ }^{3}$ Faculty of Sports Sciences, State University of Surabaya, Indonesia
}

Received June 13, 2021; Revised August 4, 2021; Accepted August 22, 2021

\section{Cite This Paper in the following Citation Styles}

(a): [1] Ermawan Susanto, Johan Irmansyah, Nur Indah Pangastuti, Fifukha Dwi Khory , "The Effect of Responsibility-Based Aquatic Teaching on the Respect and Caring of Middle School Students, "International Journal of Human Movement and Sports Sciences, Vol. 9, No. 5, pp. 955 - 963, 2021. DOI: 10.13189/saj.2021.090517.

(b): Ermawan Susanto, Johan Irmansyah, Nur Indah Pangastuti, Fifukha Dwi Khory (2021). The Effect of Responsibility-Based Aquatic Teaching on the Respect and Caring of Middle School Students. International Journal of Human Movement and Sports Sciences, 9(5), 955 - 963. DOI: 10.13189/saj.2021.090517.

Copyright $\odot 2021$ by authors, all rights reserved. Authors agree that this article remains permanently open access under the terms of the Creative Commons Attribution License 4.0 International License

\begin{abstract}
Accident cases in the aquatic teaching indicate that students have not yet formed an attitude responsibility. The purpose of this study was to determine whether there is an effect of responsibility-based aquatic teaching on respect and caring. This study used an experimental method with one group pretest-posttest design. The study population was eighth-grade students who studied the aquatic lesson (the experimental condition, $\mathrm{n}=75$ ). The research sample was selected using cluster random sampling. The 75 participants consist of 40 boys and 35 girls. The experimental test of the effect of the responsibility-based aquatic teaching was carried out for 10 sessions. By analyzing the paired sample t-test data, the results show that the students who took the aquatic lesson demonstrated that there is significant effect between responsibility-based aquatic teaching on increasing student' respect $(\mathrm{p}<.05, \mathrm{~d}=0.14)$ and on increasing student' caring $(\mathrm{p}<.05, \mathrm{~d}=0.95)$. Data analysis shows that there is a significant influence of responsibility-based aquatic teaching on increasing student respect and caring $(\mathrm{t}=$ $6.8575, \mathrm{p}=0.00<0.005)$, so that responsibility-based aquatic teaching is effective in increasing the respect and caring of students. Current studies indicate that the effect of that responsibility-based aquatic teaching has an impact on student responsibility. This attitude appears in an enhancing aspect: respect and caring. Responsibility-based aquatic teaching in this study creates a meaningful and more responsible learning environment. Research findings also suggest that responsibility-based aquatic teaching
\end{abstract}

provides a strong framework for creating a positive and meaningful learning environment. This is relevant to the use of responsibility teaching models in physical education in middle schools.

Keywords Responsible Learning, Water Activities, Physical Education, Aquatic, Respect \& Caring

\section{Introduction}

In recreational aquatic activities, drowning appears to be a tremendous cause of death [1]. One data report reported life-threatening diving experiences were mostly carried out by adolescents who had participated in some swimming activities (98\%) or other water activities (94\%), and more than a third (37\%) a life-threatening submersion experience [2]. The city of Yogyakarta is known as the city of education in Indonesia. But at the beginning of 2019, we were all shocked by the presence of middle school students who died during activities on the river. At least six students were killed and dozens of others went missing after a flash flood reportedly swept away more than 250 students who were trekking on the banks of the Sempor River in Sleman, Yogyakarta [3]. The teacher is fully responsible for this terrible incident. This can happen because the human mind is not constant from time to time, causing something dangerous for oneself and others. Preliminary survey 
shows that $40 \%$ incidence of near drowning occurred because of the absence of Standard Operational Procedure on safety in the pool. Based on the spot, $70 \%$ of the victims drowned in public pools. An alarming number of injuries and drowning events occur at lifeguarded swimming pools [4]. This incident is a serious problem that can threaten the health and safety of students. The phenomenon might illustrate the low level of responsibilities.

Aquatic lesson aims to develop motoric aspects in the form of basic swimming skills and also provides students with opportunities as many as possible to be directly involved in the learning process both cognitively and affectively. However, reality in school still shows that swimming learning is about physical activity emphasizes physicality, physical skills development, and abilities [5]. Epidemiological data indicate that children are a high-risk group for drowning and while progress has been made in understanding toddler drowning, there is a lack of empirical evidence regarding the drowning risk and protective factors inherent for adolescents and young adults [6].

Thus, the thing in aquatic teaching has not succeeded in realizing the full educational goals. For this reason, there are specific new breakthroughs that can be used in swimming lesson to develop personal responsibility, interaction, and changes in social behavior. Teaching Personal and Social Responsibility has a specific goal that is the emphasis on personal development and responsibility of students [7]. Learning approach is more oriented towards student, namely respect and self-actualization.

Indonesia is a country with a majority of territorial waters, a sea area of approximately 5.6 million $\mathrm{km}^{2}$ with a coastline of $81,000 \mathrm{~km}$, with a variety of potential abundant natural resources in it. In the context of water activities, the Indonesia has characteristics and a wide area that is very suitable for developing aquatic activities. Thus, the school curriculum includes swimming lesson as material. With a large area of water, the potential danger is also greater. Therefore, the aquatic lesson curriculum emerged. Which aims to equip students to be adept at swim and have an attitude of responsibility in learning.

One of the learning models for learning responsibility attitudes is the TPSR model, which is a form of holistic learning model that can be used in learning physical subjects in schools. The TPSR model seeks to increase responsibility for motion learning and overcome risk factors and avoid problems [8]. The program is used in the TPSR model likes values of respect, effort, self-direction, caring and leadership. These values are issued through strategies that discuss support, empowerment, and transfer of values in physical education and how to consider it with a combination of life skills and movement skills.

The TPSR model has been based on concepts that foster resilience, which can have a positive impact on students' future involvement [9]. Teachers in the implementation of teaching need to use appropriate instructional approaches such as teaching TPSR [10]. The core of the TPSR model is to discuss two values of responsibility one of which focuses on personal welfare and the other on social welfare or helping others [11]. Thus, those who participate in the TPSR model learn how to develop personal and social responsibility gradually, experiencing attitudes and behaviors that help them become responsible people [12].

The TPSR model can provide an effective framework for promoting responsibility throughout the middle school curriculum [13]. It is also hoped that through this study the increased responsibility that forms in schools can be inherent brought to life in the community. This conclusion is supported by the results of research showing that the TPSR model appears to promote the acquisition of social skills by encouraging students to imagine their daily activities similar to scenarios in physical education classes, where they are encouraged to behave responsibly [14].

However, the facts show that the process of aquatic lesson conducted at the middle school level is not optimal. This is reflected in the results of observations made by researchers such as plans for aquatic learning programs are incomplete. Teaching emphasizes motor development with little regard for psychological development and student safety. In the aspect of safety, there are a number of cases that show low attitude towards responsibility of students, for example drowning. Therefore, the results of this study aim to formulate an instrument of personal and social responsibility attitudes in aquatic lesson. This condition is strengthened by the results of a survey conducted by researchers, found the fact that teachers have not been able to compile an attitude instrument of responsibility. The researcher then considered a number of alternatives for the preparation of instruments containing material: introduction to water, water game, freestyle swimming, backstroke swimming, breaststroke swimming, and water safety. It is hoped that this instrument can be used to measure students' responsibility in swimming lesson in middle schools. This study aims to determine the effect of responsibility-based aquatic teaching on respect and caring of middle school student.

\section{Materials and Methods}

\subsection{Participants}

Participants were students from five schools that are located in the Yogyakarta City. The schools selected consist of public schools and private schools. Participants used in this study were students of eighth-grade students in middle School. The research sample consisted of 75 students who were selected using cluster random sampling. From the 75 participants consisting of 40 boys and 35 girls. Participant criteria for this study are: a) students who 
take aquatic lessons, b) have responsibility scores below the minimum completeness criteria, c) have at least 2 out of 5 low responsibility scores such as lack of respect, lack of care, annoy friends, and etc. Researchers have obtained permission of the school to carry out research during 10 meetings in the selected swimming pool. Requirements as a swimming teacher or trainer in this intervention are those who have a certificate of training level $\mathrm{C}$ or provincial level. In addition, this teacher or swimming trainer has attended a 2-day workshop specifically for research purposes in this aquatic teaching responsibility.

\subsection{Intervention}

The experimental test of the effect of the responsibility-based aquatic teaching was carried out for 10 sessions (each week, 90 minutes each). Those who act as external observers of responsibility-based aquatic teaching intervention programs are physical education teachers. In the table below, the material used as treatment in finding out the level of student responsibility is presented.

Table 1. Material Intervention and Experimental Material

\begin{tabular}{|c|c|c|}
\hline Sesion & Responsibility Level & Material \\
\hline 1 & & \multicolumn{2}{|c|}{ Pretest } \\
\hline 2 & Level 1 & Water Orientation \\
\hline 3 & Level 1 & Water Games \\
\hline 4 & Level 2 & Freestyle Swimming \\
\hline 5 & Level 2 & Freestyle Swimming \\
\hline 6 & Level 3 & Breast Stroke Swimming \\
\hline 7 & Level 3 troke Swimming \\
\hline 8 & Level 4 & Water Safety \\
\hline 9 & Level 4 Water Safety \\
\hline 10 & & \multicolumn{2}{|c}{ Posttest } \\
\hline
\end{tabular}

The treatment intervention that was given focus on questions about the level of responsibility that had been done. At the end of the aquatic lesson, the teacher asks questions related to the level of success (e.g. Level 1: do you show respect for each other during the activity? Level 2: are you putting your maximum effort into your assignment?). The material used as treatment intervention in this study includes an introduction, core exercises, and a closing. Responsibility-based aquatic teaching that is applied includes awareness talk, lesson focus, group meetings, and reflection time.

\subsection{Measures}

Freestyle swimming activity is measured through an assessment of body position movements, arm movement, leg movement, breathing, and coordination.
Table 2. Evaluate the Swimming Strokes

\begin{tabular}{|c|c|c|c|c|c|c|c|}
\hline Technique & & Motion Analysis & \multicolumn{5}{|c|}{ Score } \\
\hline Body Position & $\begin{array}{l}1 . \\
2 . \\
3 .\end{array}$ & $\begin{array}{l}\text { Streamline position } \\
\text { Almost streamline } \\
\text { Not streamline }\end{array}$ & 5 & 4 & 3 & 2 & 1 \\
\hline $\begin{array}{c}\text { Arm } \\
\text { Movement }\end{array}$ & $\begin{array}{l}1 . \\
2 . \\
3 .\end{array}$ & $\begin{array}{l}\text { Complete arm phase } \\
\text { Incomplete } \\
\text { No arm phase yet }\end{array}$ & & & & & \\
\hline $\begin{array}{c}\text { Leg } \\
\text { Movement }\end{array}$ & $\begin{array}{l}1 . \\
2 . \\
3 .\end{array}$ & $\begin{array}{l}\text { Complete leg phase } \\
\text { Incomplete } \\
\text { No leg phase yet }\end{array}$ & & & & & \\
\hline $\begin{array}{c}\text { Breath } \\
\text { Movement }\end{array}$ & $\begin{array}{l}1 . \\
2 . \\
3 .\end{array}$ & $\begin{array}{l}\text { Breath to the side } \\
\text { Breath forward } \\
\text { Can't phase the breath }\end{array}$ & & & & & \\
\hline Coordination & $\begin{array}{l}1 . \\
2 . \\
3 .\end{array}$ & $\begin{array}{l}\text { Good } \\
\text { Moderate } \\
\text { Less }\end{array}$ & & & & & \\
\hline
\end{tabular}

\subsection{Data Collection}

The experimental procedure consists of four stages: (a) confirmation, (b) pretest, (c) intervention, and (d) posttest. During the confirmation stage which took place during even semester 2019, each student took part in an aquatic class for 10 meetings. Each student then enters the pretest stage, which includes two forms of test (1). Aquatic test which consists of water orientation test, water games, freestyle swimming, breaststroke swimming, and water safety; (2). Checklist of responsibility components that appear during the aquatic pretest process, then see whether the responsibility component has appeared or not. The components of responsibility that are monitored are respect and caring. When conducting pre-aquatic tests, students are accompanied by a teacher with a teacher: student ratio of $1: 10$.

\subsection{Data Analysis}

In connection with the experimental research design, namely One-Group Pretest and Posttest Design, only one intervention group is needed without a control group. Data are analyzed using paired sample t-test. To find out the variable of responsibility, an inferential test was carried out using a paired sample $\mathrm{t}$ test, while to prove the difference in the effect of the two treatments, an independent sample $t$ test was performed. The prerequisite test includes a normality test and a homogeneity test. Responsibility-based aquatic teaching materials include discussion of awareness, focus of learning, group meetings, and reflection time. Instrument for measuring of responsibility used the Tool for Assessing Responsibility-Based Education [15]. The number of questionnaire items for respect variable were 28 items and for caring variable as many as 30 items with a validity level of 0.47 and a reliability of 0.98 . Table 3 describes the distribution of treatment in aquatic teaching in middle schools. 
Table 3. Responsibility-Based Aquatic Teaching Sequence

\begin{tabular}{|l|l|}
\hline Teaching Sequence & Activities \\
\hline Preliminary & Apperception \\
& Warming Up \\
\hline & Awareness Talk \\
& Lesson Focus: \\
& Presented the problem \\
The Core of Teaching & Identified the problem \\
& Data analysis \\
& Answer the problem \\
& Practicing movement \\
& Group presentation \\
\hline \multirow{3}{*}{ Closing Lesson } & Group Meeting \\
& Reflection Time \\
& Cooling Down \\
\hline
\end{tabular}

\section{Results}

Description of the results of research on the variable attitude of responsibility of students in aquatic lesson was taken at the time of the pretest and posttest. The pretest results, illustrated in Table 4 shows that the average value of the attitude of responsibility of students in responsibility-based aquatic teaching. Likewise, based on the results of the post-test, the average value of the attitude towards responsibility of students. There are differences in the pretest and post test scores. To determine the variable of responsibility, an inferential test was performed using paired sample t test, while to prove the difference in the effects of the two treatments was carried out with independent sample t test.

Table 4. Descriptive statistics differences pretest and posttest

\begin{tabular}{|c|c|c|}
\hline Pretest & Posttest & Differences Pre-post \\
\hline $\bar{x}=2,6384$ & $\bar{x}=3,1243$ & $\bar{x}=0,4859$ \\
\hline$S D=0.5463$ & $S D=0.4097$ & $S D=0.1721$ \\
\hline$N=75$ & $N=75$ & $N=75$ \\
\hline
\end{tabular}

To analyze the data, the researcher used a paired sample t-test to prove the importance of the effect of responsibility-based aquatic teaching in increasing student respect and caring. The analysis used a two-sided test and a significance level of 0.05 . Data analysis illustrated in Table 5 shows that there is a significant influence of responsibility-based aquatic teaching on increasing students' respect and caring $(\mathrm{t}=6.376, \mathrm{p}=0.00<0.005)$, so that responsibility-based aquatic teaching is effective in increasing the respect and caring of students.

Table 5. Paired sample t-test for Responsibility Level

\begin{tabular}{|c|c|c|c|}
\hline Group & $\boldsymbol{t}$ & $\boldsymbol{d f}$ & Sig. (2-tailed) \\
\hline $\begin{array}{c}\text { Responsibility-based on } \\
\text { aquatic teaching }\end{array}$ & 6.376 & 74 & 0.000 \\
\hline
\end{tabular}

\subsection{Normality Test}

Prerequisite tests which include tests of normality and homogeneity can be seen in Table 7 and 8 . Before conducting data analysis, it is necessary to meet the analysis requirements to prove that the data are normally distributed. It is proven by the normality test. The findings of the data normality test analysis in Table 6 show that the value of the attitude of respect variable both pretest and posttest values are normally distributed. The value of caring variable, both pretest and posttest values, are also normally.

Table 6. Normality Test Processing Results

\begin{tabular}{|c|c|c|c|c|}
\hline \multicolumn{2}{|c|}{$\begin{array}{c}\text { Experiment } \\
\text { Data Group }\end{array}$} & $\begin{array}{c}\text { Kolmogorov-Smirnov } \\
\text { Test }\end{array}$ & P-value & Distribution \\
\hline \multirow{2}{*}{ Respect } & Pre & 0.411 & $>0.05$ & Normal \\
\cline { 2 - 5 } & Post & 0.512 & $>0.05$ & Normal \\
\hline \multirow{2}{*}{ Caring } & Pre & 0.721 & $>0.05$ & Normal \\
\cline { 2 - 5 } & Post & 0.936 & $>0.05$ & Normal \\
\hline
\end{tabular}

\subsection{Homogeneity Test}

Likewise, before data analysis, it is necessary to meet the analysis requirements to prove that the data are homogeneous. It is proven by homogeneity test. The findings of the data homogeneity test analysis in Table 7 are known for the value of respect both the pretest value and the posttest value, indicating that it is homogeneous distributed. The value of caring variable, both pretest and posttest values, also showed homogeneous distribution.

Table 7. Homogeneity Test Processing Results

\begin{tabular}{|c|c|c|c|c|}
\hline \multicolumn{2}{|c|}{$\begin{array}{c}\text { Experiment } \\
\text { Data Group }\end{array}$} & $\begin{array}{c}\text { Levene } \\
\text { Statistic }\end{array}$ & Probability & Varian \\
\hline \multirow{2}{*}{ Respect } & Pre & 0.140 & $>0.05$ & Homogen \\
\cline { 2 - 5 } & Post & 0.447 & $>0.05$ & Homogen \\
\hline \multirow{2}{*}{ Caring } & Pre & 0.630 & $>0.05$ & Homogen \\
\cline { 2 - 5 } & Post & 0.912 & $>0.05$ & Homogen \\
\hline
\end{tabular}

\subsection{Hypothesis Test}

Based on the hypothesis test, the following results were obtained.

Table 8. Results Analysis of Paired Sample Tests

\begin{tabular}{|c|c|c|c|c|c|c|}
\hline \multicolumn{2}{|c|}{} & \multicolumn{3}{|c|}{ Paired Differences } & \multirow{2}{*}{ t } & \multirow{2}{*}{ df } \\
\cline { 3 - 5 } & Mean & SD & SE & & \\
\hline Pair 1 & Respect & -7.064 & 5.575 & .964 & -7.451 & 74 \\
\hline Pair 1 & Caring & -8.132 & 9.280 & .725 & -4.380 & 74 \\
\hline
\end{tabular}

$\mathrm{SD}=$ Standart Deviasi, $\mathrm{SE}=$ Standart Error of Mean

\subsection{The Effect of the Responsibility-Based Aquatic Teaching on Respect}

The results of the paired sample $t$ test calculation on the responsibility variable in Table 8 obtained the value of 
t-count greater than t-table. This means that there is a significant difference between the pretest and posttest mean scores of students' respect in the responsibility-based aquatic teaching. This is reinforced by the acquisition of the mean value of $t$-count. This shows the posttest mean value (after the responsibility-based aquatic teaching treatment was given) is higher and significant than the pretest mean value (the average before treatment was given). Therefore, it can be concluded that the responsibility-based aquatic teaching has a significant influence on the attitude of respect. The influence of the responsibility-based aquatic teaching was seen in the change in attitude of students, they were more serious in completing their swimming assignments, respecting teacher instructions, participating actively, and respecting for friends. Learning to respect the rights and feelings of others had three related aspects, namely self-control, the right to resolve conflicts peacefully, and the right of everyone to be included in every activity in the class. The responsibility-based aquatic teaching developed in this study, modifies the TPSR model so that it was appropriate to measure the responsibility of middle school students consisting of two variables: respect and caring.

\subsection{The Effect of the Responsibility-Based Aquatic Teaching on Caring}

The results of paired sample t test calculations on social behavior variables obtained t-count values greater than t-table. This could be interpreted that there was a significant difference between the pretest and posttest mean scores of students' caring in the responsibility-based aquatic teaching. This is reinforced by the acquisition of the mean value of t-count shown in Table 8 . This shows the posttest mean value (after the treatment of the responsibility-based aquatic teaching was given) is higher and more significant than the pretest mean value (the average before the treatment is given), so it is concluded that the responsibility-based aquatic teaching has a significant influence on caring. The motion material applied through the responsibility-based aquatic teaching consist of water orientation, water games, freestyle swimming, breaststroke swimming, and water safety, each having a different form of activity in increasing responsibility. Table 9 shows the form of water activities as part of the responsibility-based aquatic teaching material.

Table 9. Various Types of Water Activities

\begin{tabular}{|c|c|c|}
\hline Water Orientation & Water Games & $\begin{array}{c}\text { Swimming } \\
\text { Styles }\end{array}$ \\
\hline Move legs while sitting & Catch fish & Legs movement \\
Move legs when prone & Shooting star & Arms movement \\
Swing arm & Water polo & Breathing \\
Running in water & Dragon Snake & Coordination \\
Jump spikes & Water rickshaw & Swimming \\
\hline
\end{tabular}

In addition to statistical evidence, research results were also supported by the actuality of field studies based on observations on the learning process using the responsibility-based aquatic teaching. Based on observations, groups of students who intervened using the responsibility-based aquatic teaching showed an increase in their responsibilities, seen from their attitudes during the learning activities. During the learning process from the beginning to the end of the intervention, students showed significant attitude changes. The change in attitude observed during the test showed that students appreciated their friends or teacher who was talking. Students were also willing to work together and be actively involved in the aquatic lesson process by helping one another and helping to explain difficult movements. In addition, students could learn independently with their groups in solving problems of learning assignments given by the teacher. They could also motivate one another and showed concern for other friends, especially when their friends had difficulty doing mobile learning tasks.

\section{Discussion}

The results of this study show us that the real hazards of swimming pool activities can be prevented by applying the TPSR model to aquatic teaching in secondary schools. The respect and caring traits developed in these experimental tests were proven to be successful in preventing hazards in swimming pool activities, namely drowning and death. The effect of responsibility-based aquatic learning can be seen in changes in student attitudes, namely being more serious in completing their swimming learning responsibilities, respecting lecturers' instructions, participating actively, respecting friends and helping friends. The change in attitude observed during the test shows that students value friends and teachers. Students are also willing to cooperate and be actively involved in the aquatic learning process by helping each other and explaining difficult swimming movements. In addition, students can learn independently with their groups in solving problems with learning assignments given by the teacher. They can also motivate each other and show concern for their other friends, especially when their friends have trouble with difficult swimming tasks.

Physical education has the potential to increase children's personal and social responsibility, as well as to educate them to look after themselves and others in high-risk environments [40]. Likewise, the TPSR model can be used as a solution to reduce harmful things in the aquatic environment. Fatal and non-fatal drowning is a real issue. Using TPSR model to positively affect aquatic skill and knowledge could be a viable method for drastically decreasing these tragic incidences.

The main objective of this study was to explore the 
effects of an 10-week aquatic activity intervention on responsibility-based aquatic teaching among students with prior low responsibility problems. The results of this study support the hypothesis that the student responsibility value increases significantly with the provision of selected aquatic activities. These results are consistent with research on students regarding demonstrable change in an attitude of responsibility $[16,17]$.

Increased respect and caring of students occurs because the responsibility-based aquatic teaching provides more opportunities for students to integrate responsibility into aquatic lesson. The forms of water activity chosen in this study indirectly guided students to behave responsibly for themselves and others. The forms of water recognition activities, water games, swimming style, and water safety are very good forms of activities in teaching the attitude of responsibility, so that this water activity is compatible with the TPSR theory developed by Hellison. In this case the relationship between the teacher and students also became more interactive so as to enable verbal persuasion by the teacher against students or also between students and other students. Related to the influence of the responsibility-based aquatic teaching on the attitude of respect and caring behavior of students, it can be explained that social responsibility and behavior are formed by the existence of a contract of behavior before learning given by the teacher systematically starting from a simple level to a complete level. This is consistent with the research results which showed an increase in responsibility, consisting of variables of respect and caring for aquatic material at Yogyakarta Middle School [18].

Integration in responsibility-based aquatic teaching is carried out at two levels of behavior that students must achieve. The first part aims to build a positive learning environment by getting used to mutual respect for the rights and feelings of others, taking aquatic lessons, obeying the rules in the pool, and being able to control yourself from the dangers in the pool. The second part is getting used to helping each other, caring for friends who are not good at swimming, and have empathy [19].

The effect of responsibility-based aquatic teaching can be seen from changes in attitudes; students value each other more; there is no noise; they are orderly; they can listen and pay attention when the teacher gives examples. The attitude of the students is also shown by the courage to do swimming movements even though they are in a deep pool and there is no excessive fear. Another attitude that emerges is to help a friend who has not been able to do the right swimming movements. The culmination of the success of responsibility-based aquatic teaching is all the attitudes that have been acquired as examples in other environments, whether at home, school, or in social relationships. Therein lies the highest level of the developed TPSR theory, namely being a role model for others and elsewhere. Respect for others is intended to provide a psychologically and physically safe place for all students and to deal with students who need to work on issues of respect and care. Based on the research questions it can be discussed as follows:

\subsection{The Effect of the Responsibility-Based Aquatic Teaching on Respect}

The essence of the expected responsibility-based aquatic teaching shows that to succeed in their social environment, students must learn to be responsible for themselves and be responsible to others, and determine ways to control themselves, so that they can be accepted by their environment [20]. Responsibility-based aquatic teaching gradually accustoms students to behaviors that will help them become responsible and control themselves [17]. Based on the previous explanation, responsibility-based aquatic teaching is an appropriate learning tool for teaching and responsible behavior towards oneself and others.

Research on responsibility in PE has increased over the past two decades [21]. Traditionally, the application of the responsibility model has often been carried out in school or community-based programs with voluntary participation and small numbers of participants. In conclusion, the responsibility model is considered a viable and effective pedagogical approach to teaching movement. The aim of this systematic review is to analyze studies included in peer-reviewed journal TPSR models in the context of PE [22].

The results also showed that responsibility-based aquatic teaching given in the classroom had a significant effect in increasing student respect and care. Respect and care can be increased through responsibility programs using specific strategies in PE [23]. Responsibility-based aquatic teaching has increased student respect, which is indicated by the way students listen to others, do not make noise, and pay attention when teachers or other students give examples of swimming movements to do. Responsibility-based aquatic teaching is believed to have increased students' respect and care in the aspects of self-control, effort, helping others, self-direction, cooperation, communication skills, interpersonal relationships, feelings of responsibility, and sportsmanship [7]. Positive changes in motivation and active participation are also shown when students practice swimming style learning practices, this can be seen from the enthusiasm and motivation of students in completing mutually agreed programs. Freestyle swimming and breaststroke materials teach students to exert self-direction efforts in completing the swimming distance that must be covered. Changes in student responsibility are also shown by increased sensitivity to friends and the environment, students show concern and want to help others in helping with swimming material. Caring and willingness to help others is shown when other students have problems, and they help voluntarily. 


\subsection{The Effect of the Responsibility-Based Aquatic Teaching on Caring}

The results of previous studies explained that the responsibility-based learning model is an effective learning model for the development of social responsibility and student behavior [24]. The influence of responsibility-based aquatic teaching on student care is shown by caring attitude in helping friends who are in trouble. Help friends who are victims of accidents in the pool such as drowning or nearly drowning. The highest value of caring attitude is shown by being a role model not only for other friends but also in other places or in other environments. Aquatic material wrapped in responsibility-based teaching is proven to have increased students' caring attitudes. Swimming material assistance movements, helping victims in the pool, helping friends, and simulating Cardio Pulmonary Resuscitation have created a high caring attitude towards students. Aid material in the swimming pool is different from the material in other physical education classes, considering that help is very important as a provision for students to face challenges in the water environment.

Responsibility teaching strategies can be carried out in the form of direct instruction, group discussions, peer instruction, learning to work together, working independently, self-reflection, and making their own decisions. Provide students with opportunities to integrate responsibility into learning and enhance student active roles. From the description above, it can be seen that responsibility-based aquatic teaching integrates the formation of positive behavior and supports student academic improvement [25]. According to Li, Wright, Rukavlna, \& Pickering [26], the success of education does not only depend on academic potential, but also on students' respect and responsibility for others. The responsibility teaching model is considered to be the ideal framework for designing physical education classes and curricula.

There are five stages developed into this responsibility-based aquatic teaching, namely counseling time, awareness talk, learning, group meetings, and reflection time [11]. Counseling time is the length of time it takes the teacher to prepare for learning. Awareness talk is a session to remind students of the responsibilities they want to achieve, and in this session students can make a contract with the teacher about the target level of responsibility to be achieved in the learning that day. During these sessions, teachers use specific instructional strategies to integrate responsibility into aquatic teaching.

Group meetings are a practical learning tool for students to learn democratic values, this session aims to provide opportunities for students to express their views about the learning process at that time, about their classmates, and how effective the instructional instruction is delivered by the teacher. An important goal to be achieved in this group meeting is to provide students with practical experience about the decision-making process in groups and how they should behave when they get different perceptions. The reflection time for the last session of responsibility-based aquatic teaching is the time for reflection before students leave the classroom. Reflection time is designed for students to reflect on and evaluate how much they respect the rights and feelings of others, how much effort and participation they show during the learning process, and the possibility of applying the attitude of target student responsibility outside of aquatic lessons.

Implementing responsibility-based aquatic teaching can help students take responsibility for their own behavior and understand what it means to demonstrate that behavior. This means that the developed aquatic teaching has shown a positive influence on student responsibility. This is indicated by the increasing variable of respect and concern. The results of this study are relevant to the use of responsibility teaching models in physical education that have been studied and applied in several countries. This relevance can be seen from the results of research applied to physical education classes $[27,28,29,30]$. This indication is relevant to the fact that the formation of responsibility cannot be done instantly, but it takes a long and sustainable time [31]. The following are some of the relevant research results: Results of research applied to extracurricular programs $[32,33]$. The results of the research were applied to community-based projects [34, 35]. The results of the study were applied to sports [36].

From the relevant research, it is found that teaching of responsibility gives positive results for students. A review of 26 studies examining the effectiveness of teaching responsibility on positive youth development found that 19 studies shows increased respect, effort, independence, caring and leadership capacity among athletes and physical education students [7]. Other research results from 22 studies of teaching responsibility in physical education classrooms concluded that this teaching contributed to a series of positive behavioral, social, emotional, psychological, and educational outcomes. For example, research shows increased effort, empathy, independent learning, leadership skills, caring, teamwork, and personal \& social responsibility, as well as a reduction in behavioral problems, such as violence against peers and absence from school [37, 38, 39].

The findings from this review of responsibility-based aquatic teaching show the following implications that in PE, especially aquatic must be harmonized with cultural differences between students, the need to motivate students continuously, and teachers to set an example in school life. Responsibility-based aquatic teaching is beneficial with the involvement of children's physiological and teacher pedagogical resources in the teaching process. The findings from this review of responsibility-based aquatic teaching show the following implications that in PE, especially aquatic must be harmonized with cultural differences 
between students, the need to motivate students continuously, and teachers to set an example in school life.

\section{Limitations}

This study had some limitations that warrant caution with the interpretation of its results. Responsibility-based aquatic teaching, which is a learning model based on the theory of responsibility, will be carried out well, if the basic swimming skills of students are homogeneous. The fact is that there are some students who have limited or not proficient swimming basic skills. Teaching will be carried out well if the teacher starts with lesson planning activities that are specifically designed to develop responsibility. The fact is that teachers find it difficult to plan for teaching this responsibility. Researchers also find it difficult to find secondary schools that carry out aquatic teaching intensively in one semester considering that not all schools are able to implement it due to the large cost factor. This teaching has a fairly complete component as a teaching model that involves students, pool media, teachers, physical activities, so that the information produced is comprehensive to measure children's responsibility [5].

\section{Conclusions}

The current studies indicates that the effect of that responsibility-based aquatic teaching has an impact on students' responsibility. This attitude appears in an enhancing aspect: respect and caring. Research findings also suggest that responsibility-based aquatic teaching provides a strong framework for creating a positive and meaningful learning environment. This is relevant to the use of responsibility teaching models in physical education in middle schools.

\section{REFERENCES}

[1] Driscoll, T. R., Harrison, J. A., \& Steenkamp, M., "Review of the role of alcohol in drowning associated with recreational aquatic activity," Injury Prevention, 2004. https://doi.org/10.1136/ip.2003.004390

[2] Moran, K., "Risk of Drowning: The Iceberg Phenomenon Re- visited Risk of Drowning," International Journal of Aquatic Research and Education, 4(4), 115-126, 2010. Retrieved from http://scholarworks.bgsu.edu/ijare

[3] Https://www.thejakartapost.com, "At least six dead after flash flood sweeps away 250 students in Yogyakarta", 2019. https://www.thejakartapost.com/news/2020/02/21/at-leastsix-dead-after-flash-flood-sweeps-away-250-students-in-y ogyakarta.html
[4] Schwebel, D. C., Jones, H. N., Holder, E., \& Marciani, F., "The Influence of Simulated Drowning Audits on Lifeguard Surveillance and Swimmer Risk-Taking at Public Swimming Pools," International Journal of Aquatic Research and Education, 5(2), 2011. https://doi.org/10.250 35/ijare.05.02.08

[5] Rahayu, N. I., Suherman, A., \& Jabar, B. A., "Hybridising Teaching Personal Social Responsibility (TPSR) and Problem Based Learning (PBL) in Physical Education," Jurnal Pendidikan Jasmani dan Olahraga, 3(2), 2018. DOI: 10.17509/jpjo.v3i2.12395

[6] Petrass, L. A., \& Blitvich, J. D., "Preventing adolescent drowning: Understanding water safety knowledge, attitudes and swimming ability. The effect of a short water safety intervention," Accident Analysis and Prevention, 70, 188194, 2019. https://doi.org/10.1016/j.aap.2014.04.006

[7] Hellison, D. \& Walsh, D., "Responsibility-based youth programs evaluation: Investigating the investigations," Quest, 54(4) 292-307, 2002. DOI: 10.1080/00336297.2002 .10491780

[8] Anthony E., Alter C., \& Jenson, J., "Development of a Risk and Resilience-Based Out-of-School Time Program for Children and Youths. Social Work, 54(1), 45-55, 2009. DOI: $10.1093 / \mathrm{sw} / 54.1 .45$

[9] Walsh, D., "Helping youth in underserved communities envision possible futures: An extension of the teaching personal and social responsibility model," Research Quarterly for Exercise and Sport, 79(2), 209-221, 2008. DOI: $10.1080 / 02701367.2008 .10599484$

[10] Alcalá, D., Río, J., Calvo, G., \& Pueyo, Á., “Comparing Effects of a TPSR Training Program on Prospective PE Teacher's in Spain, Chile and Costa Rica. Physical Education and Sport Pedagogy," 24(3), 220-232 2019 DOI: 10.1080/17408989.2018.1561837

[11] Martinek, T., \& Hellison, D., "Teaching Personal and Social Responsibility: Past, Present and Future," Journal of Physical Education, Recreation \& Dance. 87(5), 8-13, 2016. DOI: $10.1080 / 07303084.2016 .1157382$

[12] Cabalero, P., Delgado, M., \& Escarti, A, "Analysis of TPSR Model-based Programmes Applied in USA \& Spain," Journal of Human Sport \& Exercise, 2013. DOI: 10.4100/jhse.2012.82.10

[13] Escarti, A., Goig R., \& Wright, P.M, "Assesing the Implementation Fidelity of a School-based Teaching Personal and Social Responsibility Program in PE," Journal of Teaching in Physical Education, 37(1) 12-23, 2017. DOI: 10.1123/jtpe.2016-0200

[14] Umegaki, A., Otomo, S., Minamishima, E., Ueta, K., Fukada, N., Yoshii, T., \& Miyao, N., 'Study of the transfer and maintenance of the effects of the TPSR model in junior high school physical education classes,". Taiikugaku Kenkyu (Japan Journal of Physical Education, Health and Sport Sciences), 61(2), 503-516, 2016. DOI:10.5432/jjpeh ss.15069

[15] Wright, P. M., \& Craig, M. W., "Tool for assessing responsibility-based education (TARE): Instrument development, content validity, and inter-rater reliability," Measurement in Physical Education and Exercise Science, 15(3), 204-219, 2011. DOI: 10.1080/1091367X.2011.5900 
84

[16] Escarti, A., Goig R., \& Wright, P.M., "Assesing the Implementation Fidelity of a School-based Teaching Personal and Social Responsibility Program in PE," Journal of Teaching in Physical Education, 37(1) 12-23, 2017. DOI: 10.1123/jtpe.2016-0200

[17] Cabalero, P., Delgado, M., \& Escarti, A., "Analysis of TPSR Model-based Programmes Applied in USA \& Spain," Journal of Human Sport \& Exercise, 2013. DOI: 10.4100/jhse.2012.82.10

[18] Nurina, T., \& Sukoco, P., "Upaya Peningkatan Karakter Siswa SMA dalam Permainan Bola Basket melalui Model TPSR'” Jurnal Keolahragaan, 2(1), 77-87, 2014 https://doi.org/10.21831/jk.v2i1.2605

[19] Elias, M.J., "The Connection Between Academic and Socialemotional Learning," The Fundamental Connection of Sel/Ei, Academic Performance, and the Process of Learning, pp. 4-14, 2015

[20] Escarti, A., “Applying TheTeaching Personal and Social Responsibility Model (TPSR) in Spanish Schools Context: Lesson Learned," Agora para la educación física y el deporte. 14(2), 178-196, 2012

[21] Lee, O., \& Choi, E., "The influence of professional development on teachers' implementation of the Teaching Personal and Social Responsibility model," Journal of Teaching in Physical Education, 34(4), 603-625, 2015. DOI: 10.1123/jtpe.2013-0223

[22] Pozo, P., Grao-Cruces, A., \& Pérez-Ordás, R., “Teaching personal and social responsibility model-based programmes in physical education: A systematic review," European Physical Education Review, 24(1), 56-75, 2018. DOI $10.1177 / 1356336 \times 16664749$

[23] Salamuddin, N., \& Harun, M. T., "Facilitating the process of learning social skills through humanistic physical education," In Procedia - Social and Behavioral Sciences, 9, 223-227) 2010. DOI: 10.1016/j.sbspro.2010.12.140

[24] Escarti, A., Gutiérrez, M., Pascual, C., \& Marín , D., "Application of Hellison's Teaching Personal and Social Responsibility Model in Physical Education to Improve Self-Efficacy for Adolescents at Risk of Dropping-out of School," The Spanish Journal of Psychology, 13(2), 667-676, 2010. DOI: 10.1017/S113874160000233X

[25] Anthony E., Alter C., \& Jenson, J., ”Development of a Risk and Resilience-Based Out-of-School Time Program for Children and Youths,". Social Work, 54(1), 45-55, 2009. DOI: $10.1093 / \mathrm{sw} / 54.1 .45$

[26] Li, W., Wright, P., Rukavlna, \& Pickering, M., "Measuring students perceptions of personal and social responsibility and the relationship to intrinsic motivation in urban physical education," Journal of Teaching in Physical Education, 27(2), 167-178, 2008. DOI: 10.1123/jtpe.27.2.167

[27] Beaudoin, S., "Using responsibility-based strategies to empower in-service physical education and health teachers to learn and implement TPSR," Agora for Physical Education and Sport, 14(2), 161-177, 2012

[28] Gordon, B., Thevenard, L., \& Hodis, F., “Teaching personal and social responsibility through secondary school physical education: The New Zealand experience. New Zealand Physical Educator," 44(1) 18, 2011

[29] Hassandra, M. \& Goudas, M., “An Evaluation of a Physical Education Program for Development of Stundents Responsibility," Hellenic of Journal Psychology.7, 275-29, 2010

[30] Jinhong, J. \& Wright, R., “Application of Hellison's responsibility model in South Korea: A multiple case study of 'at-risk' middle school students in physical education," Agora para la educación física y el deporte, 14(2), 140-160, 2012

[31] Irmansyah, J., Sugiyanto, Lumintuarso, R., \& Sukoco, P., "Children's Social Skill Through Traditional Sport Games in Primary School," Cakrawala Pendidikan, 39(1), 39-53, 2020. DOI: $10.21831 /$ cp.v39i1.28210

[32] Cryan, M., \& Martinek, T., "Youth sport development through soccer: Anevaluation of an after-school program using the TPSR model," The Physical Educator, 74(1), 127-149, 2017. DOI: 10.18666/tpe-2017-v74-i1-6901

[33] Gordon, B., "Teaching personal and social responsibility through secondary school physical education: The New Zealand experience," Agora for Physical Education and Sport, 14(1), 25-37, 2012

[34] Buchanan, A., "Contextual challenges to teaching responsibility in a sports camp." Journal of Teaching in Physical Education, 20(2), 155-171, 2001. DOI: 10.1123/jtpe.20.2.155

[35] Wright, E., Withley, M., \& Sabolboro, G., "Conducting a TPSR Program for an Underserved Girls' Summer Camp,' Agora Para La Educación Física y El Deporte, 14(1), 5-24, 2012

[36] Walsh, D., Ozaeta, J., \& Wright, P. M., "Transference of responsibility model goals to the school environment: Exploring the impact of a coaching club program," Physical Education and Sport Pedagogy, 15(1), 15-28, 2010. DOI: $10.1080 / 17408980802401252$

[37] Beale, A., "Making a Different TPSR, a New Wave of Youth Development Changing Lives One Stroke at a Time," Journal of Physical Education, Recreation \& Dance. JOPERD. 5(87). PP. 31-34, 2016

[38] Jacobs, J. M., Castaneda, A., \& Castaneda, R., "Sport-based youth and community development: Beyond the ball in Chicago," Journal of Physical Education, Recreation \& Dance, 87(5), 18-22, $2016 . \quad$ DOI: $10.1080 / 07303084.2016 .1157386$

[39] Taylor, R. D., Oberle, E., Durlak, J. A., \& Weissberg, R. P., "Promoting Positive Youth Development Through School-Based Social and Emotional Learning Interventions: A Meta-Analysis of Follow-Up Effects," Child Development, 88(4), 1156-1171, 2017. DOI: 10.1111/cdev.12864

[40] Mokmin, N.A.M. "The Effectiveness of a Personalized Virtual Fitness Trainer in Teaching Physical Education by Applying the Artificial Intelligent Algorithm". International Journal of Human Movement and Sports Sciences, 8(5), 258 - 264. DOI: 10.13189/saj.2020.080514 